Article

\title{
Awe: An Important Emotional Experience in Sustainable Tourism
}

\author{
Dong Lu ${ }^{1}$ (D), Yide Liu ${ }^{2, *}$, Ivan Lai ${ }^{3, *}$ and Li Yang ${ }^{4}$ \\ 1 School of Business, Sichuan Normal University, Chengdu 610101, China; dlu@sicnu.edu.cn \\ 2 School of Business, Macau University of Science and Technology, Taipa 999078, Macau \\ 3 Faculty of International Tourism and Management, City University of Macau, Avenida Padre Tomás Pereira, \\ Taipa 999078, Macau \\ 4 School of Economics and Management, Southwest Jiaotong University, Chengdu 610031, China; \\ edta_edu@126.com \\ * Correspondence: ydliu@must.edu.mo (Y.L.); ivanlai@cityu.mo (I.L.); Tel.: +853-6299-6596 (Y.L.)
}

Received: 27 September 2017; Accepted: 24 November 2017; Published: 27 November 2017

\begin{abstract}
Awesome" is one of the most highly desirable experiences for tourists. This study investigates how tourists' awe emotion is induced when tourists visit sacred mountains and how the awe experience influences their satisfaction. A survey is administrated at a famous sacred mountain in China-Mount Emei. Results reveal that the awe experience is more elicited by the perceived vastness of natural environment for secular tourists, while is more encouraged by the perceived sanctity of religious ambience for pilgrim tourists. Awe experience is a mediator between the sense of perceptual vastness/sanctity and tourists' satisfaction. The mediation relationships through awe experience are moderated by the visitor types (pilgrims and secular tourists). Findings suggest that destination marketers should apply tourism strategies to encourage tourists' sense of awe.
\end{abstract}

Keywords: sustainable tourism; awe experiences; perceived environment; pilgrims; secular tourists

\section{Introduction}

As a mountainous country, mountain destinations occupy an important position in the scenic spots of China. In the "World Heritage List", about one-third of destinations in China are mountain destinations. Famous mountains in China are always closely related to religion. There is a Chinese adage: "all most of monks live in the famous mountains". For example, Wutai Mountain, Putuo Mountain, Emei Mountain, and Jiuhua Mountain are known as top four sacred mountains of Buddhism in China. The four Taoism holy places are also located in the top of Wudang Mountain, Qingcheng Mountain, Longhu Mountain, and Qiyun Mountain. Both natural scenery and religious culture can be found in famous mountains in China. These dual characteristics make the mountains are not only leisure tourism destinations for general holiday makers, but also meet the needs of religious believers.

As a consumption experience, emotional characteristics could be generated during travel [1]. Awe is one of the most anticipated emotional experiences for tourists [2]. Awe is a comprehensive feeling, including confused, exclaimed, fear, humility, and other complex emotions [3]. The awe emotion can be generated when individuals confront the natural wonders, the sacred religions, and other environments [3]. Sacred mountains in China are the typical places to inspire the sense of awe for visitors. As mentioned by Turner and Turner, visitors of the religious mountains are "half a pilgrim and half a tourist" [4]. For travelers who have a pilgrimage mood, their awe emotion can be induced by nature. For others (e.g., general holiday makers), their awe emotion can also be inspired by the religious atmosphere. Thus, a mountain destination must be able to make tourists feel an awe emotion. Because awe emotion can be easily induced in the grand, novel, and extreme natural 
environment [5], awe emotion affects the travel experience of tourists [2] and the awe experience can increase the satisfaction of tourists [5].

Although the tourists' awe emotion has gained the attention of scholars, most of the previous studies focus on conceptual exploration. As mentioned by Coghlan, Buckley and Weaver [2], empirical studies on awe are scarce that can help us understand how the awe emotion is generated and affects the attitude and behavior of tourists, especially in the scenario of sacred mountains with novel nature. Tourists of sacred mountains include devout religious believers and general tourists, so there is also a need for a further investigation on the differences in awe experiences between these two type tourists.

Sustainability has been conceived into two perspectives. The first perspective is described as "ethical" which is manifested in the language of "care" and "concern" about the earth as an organic autonomous lifeworld and are dominant in explicitly religious approaches that sacralize the earth; and the second one is the ecological concern with biodiversity and the long-run capability of global ecological systems to be self-maintaining [6]. The second perspective is inflexed in the developing discipline of environmental economics and then translated into technical methods of economic evaluation. This perspective is referred to as "scientific". Thus, in terms of sustainable tourism, it recognizes that, for many areas tourism was, is and will be an important form of development. It seeks to ensure that tourism developments are sustainable in the long term and wherever possible help in turn to sustain areas in which they operate [7]. Therefore, there is a range of ways to develop more sustainable forms of tourism which include lengthening stays, guide/driver capacity building, and partnership working with tour operators to improve marketing, increase satisfaction rates, and diversify the product [8]. Thus, some tourism studies referred sustainable tourism as to carrying capacity of a destination [9]. As UNWTO's explanation, sustainable tourism should also maintain a high level of tourist satisfaction and ensure a meaningful experience to the tourists [10], so this study attempts to investigate sustainable tourism in form of studying the tourists' awe experience in the context of holy mountains, exploring how visitors can generate the awe experience, and examining the mediating effects of awe on the relationship between tourists' sense of perceptual environment and satisfaction. Furthermore, this study also tries to find whether the type of tourists (pilgrims/tourists) moderates the relationship between tourists' sense of travel environment and awe.

\section{Literature Review and Research Model}

\subsection{The Emotion of Awe}

Awe is an emotional reaction when a certain aspect of an individual's original reference frame is challenged by perceptual vast stimuli [11]. The generation of awe impels individuals to self-regulate cognition and makes the individuals' schema comply with the strange and unfamiliar information [3]. As a positive emotion existing in people's daily behavior, awe not only belongs to the basic emotion of human beings, but also is regarded as individuals' basic experience with universal culture [12,13]. The key characteristics and inducing factors of awe are illustrated in Keltner and Haidt [3] prototype theory. The key features of awe include the perceived vastness and a need for accommodation. The perceived vastness is referred to the powerful force of an emotional stimulus, which can destroy or control people's willpower and make individuals feel small, powerless, scary, and humble. A need for accommodation is the feeling of confusion and surprise when an individual encounters an experience beyond the previous experience or difficult to understand. The perceived vastness can arise from three kinds of elicitors: The first is the social elicitor, such as religion, immortality, and other objects related to individuals' social and psychological exchanges. The second is the physical elicitor, such as mountains, rivers, and others which individuals can perceive intuitively through visual, auditory, tactile, and other senses. The third is the cognitive elicitor, such as the theory of relativity and other knowledge based on which the individual can develop deep cognitive processing and cognition. These three explicit elicitors can work at the same time or separately. A need for accommodation is generated from people's implicit psychology. The most common inducing factors are powerlessness, 
confusion, and the sense of "small self". Based on the appraisal theory $[14,15]$ and prototype theory [3], the generation of awe emotion is the process when an individual makes a cognitive evaluation on the external environment. On the one hand, a sense of perceptual environment is generated by evaluating the outside world and recognizing the magnificence, strength, length, and any the strong degree beyond the individual's existing understanding of the environment. On the other hand, the sense of perceptual environment can be generated through the internal evaluation. The individuals can generate the implicit psychology according to the environment and feel small, powerless, and confused. Changes in a psychological schema can make the individuals believe that it is necessary to self-regulate on the basis of the environment. In summary, the generation of awe emotion is the cognitive evaluation process on the three elicitors (social, physical, and cognitive factors) from two key aspects (perceived vastness and a need for accommodation).

\subsection{Awe in Sustainable Tourism Experiences}

The subject areas in sustainable tourism research have significantly changed in the past 20 years [16]. At the beginning, researchers studied the ways to protect a destination that include awareness of the environmental and socio-cultural impacts that tourism activities generated $[17,18]$. Recently, researchers studied how sustainable tourism can promote economic growth in a destination [19]. Therefore, sustainable tourism also aims to increase tourist satisfaction [7]. Since nature-based tourism has the strong potential to deliver awe-related experiences [5] and these experiences may enhance tourist satisfaction, awe has been regarded as an emotion closely related with sustainable tourism experiences for a long time [20,21].

To analyze awe in tourism experience, Coghlan, Buckley and Weaver [2] have studied the awe experience of 55 tourists. They found that the awe experience includes three components. The first is the physiological response, e.g., shock. The second is the comparative uniqueness, e.g., unforgettable. The third is the schema-changing for the future, e.g., inspiration. In a study on tourist experience in Antarctica, Powell, Brownlee, Kellert and Ham [5] analyzed the complexity and multiplicity of awe, including five sub-dimensions: the nature-human relationship, the spiritual connection, the transformative experience, the goal clarification, and the sense of feeling humbled.

The awe experience during travel can be generated by the vast natural scenery (e.g., majestic mountains, boundless coast, towering trees, etc.), ruins of ancient buildings (e.g., the Great Wall, the Pyramid, etc.), religious sites (e.g., the solemn halls, solemn statues, etc.) and artwork [22]. The vast natural scenery, such as a view of high places [11] and the majestic beauty of nature [23], induces the individual's sense of "small self" and makes the individual produces a sense of awe. In the religion, especially for religious believers, gods are superordinate to human beings with infinite power [24]. The sense of awe arises from the sense of "small self" when individuals are in front of gods. There are majestic mountains, panoramic view, and a sacred religious culture in sacred mountains of China, where the tourists will feel a great power from both nature and religion, and have the sense of "small self". According to Keltner and Haidt [3] prototype theory, the grand view of natural and sacred religion in religious mountains can induce the awe experience for tourists from both of the physical and social aspects. Thus, the following hypothesis is proposed:

Hypothesis 1 (H1). The perceived vastness of the natural environment (a); and the perceived sanctity of religious ambience (b) have positive impacts on the awe experience.

As a positive emotion with the transformative function, there are three basic functions of awe. The first is the self-depreciation when individuals find something larger than the self-schema [3]. The second is strengthening the connection between individuals and the outside world, promoting the spiritual pursuit and generating the prosocial motivation $[25,26]$. The third is deepening and extending the memory of the past experience [5,11]. These functions of awe encourage individuals: to increase more willingness to enjoy nature and develop creative activities [11]; to reduce concerns on 
the personal interests [26], to increase the participation in collective action [26]; to promote the prosocial tendencies by sharing, caring and supporting others [26]; to increase friendly behavior on others [25]; to strengthen ethics [20]; to yearn for the tourism destination of spiritual pursuit (by comparing with the tourism destination of enjoyment) [27]; to feel the need to have more time and be more patient; to prefer to choose the experience-oriented product (by comparing with material-oriented product); and to access life satisfaction with a higher degree [28].

The tourists' awe experience positively influences tourists' satisfaction. In tourism research, researchers found that the positive emotions promote the satisfaction of tourists [29]. As a positive emotion, awe makes individuals prolong, memorize, and relieve the past experience by enhancing the connection between the individuals and the outside world. Therefore, awe experience can induce the loyalty of behavioral and attitude [11], topophilia or "a sense of place" [30]. The awe experience inspired by the perceived vastness of the natural environment and the perceived sanctity of religious ambience during travel in the sacred mountains can also improve tourists' satisfaction. The awe experience mediates the influence of tourists' perceived vastness of the natural environment and the perceived sanctity of religious ambience on the satisfaction of tourists.

Hypothesis 2 (H2). The awe experience has a positive impact on the tourists' satisfaction.

Hypothesis 3 (H3). The awe experience mediates the influence of tourists' perceived vastness of the natural environment (a) and the perceived sanctity of religious ambience (b) on the tourists' satisfaction.

\subsection{Awe in Pilgrims and Secular Tourists}

Religion is a basic element of culture and is closely related to people's life [31]. Religion influences people's basic necessities, social and political attitudes, and travel motivations and behaviors [32,33]. Rinschede [34] found that travel behavior, including travel style, transportation selection, seasonal demand, and socialization, are influenced by people's religious beliefs. Religious beliefs may also moderate the relationship between tourists' sense of perceptual natural environment/religious atmosphere and awe.

In the pilgrimage and sustainable tourism literature, scholars recognized two different types of travelers based on tourists' experience and motivation: pilgrims and secular tourists [35,36]. The main difference between these two groups of travelers is their travel motivation. Pilgrims' travel motivation is driven by sacred or spiritual desires. Secular tourists are motivated by secular interests or pleasure [37,38]. Nyaupane, Timothy and Poudel [36] found that religious tourists treat themselves as pilgrims in sacred places and have a stronger religious motivation. Secular tourists treat themselves as general tourists and have a more recreational or cultural motivation in sacred places [27]. Sacred places arouse strong religious enthusiasm for pilgrims. At the same time, these places stimulate a sense of wonderment and cultural inspiration for secular tourists.

Due to the different tourism motivations, the awe experience of pilgrims and secular tourists may be induced by different stimuli. For traveling in sacred mountains, pilgrims generate a strong religious motivation to have more spiritual experiences. The humility before gods arouses the fear of gods. Secular tourists have a strong leisure motivation and are more likely to feel the stimulation of natural scenery. The sense of "small self" toward the grand nature makes the individual generate the sense of awe for nature. In a study on awe experience between religious believers and non-religious people, Preston and Shin [39] found that the spiritual experiences, including the personal transcendence, connection, and wonder, can induce people's awe experience. However, the awe of religious believers is from the spiritual experiences of explicit religious events or life/death events. The awe of non-religious people is more likely from the spiritual experience of nature, peak, science, yoga, or meditation. For traveling in sacred mountains in China, pilgrims' awe experience is from statues, religious instruments, religious rituals, and religious events. The secular tourists' awe experience is more 
likely to be generated in the steep mountains, panoramic view, towering trees, and other natural scenery. Therefore, the type of tourists (pilgrim/secular tourists) may moderate the relationships of the perceived vastness of the natural environment and the perceived sanctity of religious ambience on the awe emotion. Specifically, in the scenario of religious places, the impact of pilgrims' perceived vastness of the natural environment on awe should be weaker by comparing with the secular tourists. However, the impact of pilgrims' perceived sanctity of religious ambience on awe is stronger. Further, the type of tourists (pilgrim/secular tourists) also moderates the awe experience impacts on the relationships of the perceived vastness of natural environment and the perceived sanctity of religious ambience on the tourists' satisfaction. That is, the mediation relationship of awe on tourists' sense of perceptual environment/religious atmosphere and satisfaction depends on whether the tourists are pilgrims or secular tourists.

Hypothesis 4 (H4). For pilgrims, the impact of the perceived vastness of the natural environment on awe experience is weaker (a); and the impact of the perceived sanctity of religious ambience on awe is stronger (b), in comparison to secular tourists.

Hypothesis 5 (H5). The mediating effects of the perceived vastness of the natural environment (a) and the perceived sanctity of religious ambience (b) on satisfaction through the awe experience are moderated by type (pilgrims/secular tourists) of tourists.

Specifically, by comparing with the secular tourists, the mediating effect of pilgrims' awe experience on the perceived vastness of the natural environment (a) and satisfaction should be weaker. The mediating effect of pilgrims' awe experience on the perceived sanctity of religious ambience (b) and satisfaction should be stronger.

In summary, the following model is proposed (Figure 1). For traveling in sacred mountains of China, the vastness of natural environment and the sanctity of religious ambience stimulate the tourists' awe experience, and increase the satisfaction of the tourists. The type (pilgrims/secular tourists) of tourists negatively moderates the positive impact of the perceived vastness of the natural environment on awe experience, and positively moderates the positive impact of the perceived sanctity of religious ambience on awe experience. Awe experience mediates the relationship between the sense of perceptual environment and the tourists' satisfaction. The mediating effect of awe experience on the relationship between the perceived environment and the tourists' satisfaction depends on the type of tourists (pilgrims/secular tourists).

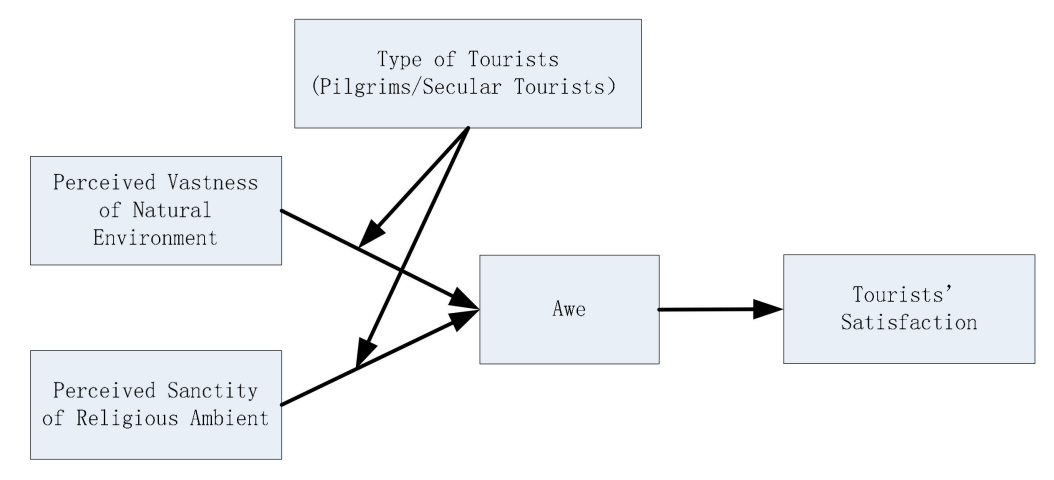

Figure 1. The conceptual model of moderated mediation.

\section{Method}

\subsection{Study Site and Sampling}

Although there are many Buddhist holy sites in Asia, the four famous mountains in China-Mount Emei, Mount Wutai, Mount Putuo, and Mount Jiuhua-are regarded as the four sacred places 
of Chinese Buddhism. Temples and monasteries were built in these four mountains since the Han Dynasty (206 BC-220 AD), along with the introduction of Buddhism from India. Currently, these four mountains are famous sacred places and tourist destinations for both Chinese and international tourists. Mount Emei is located in Sichuan Province in China with a 154 square kilometers scenic area. Wanfo Top, the main peak of Mount Emei, is $3099 \mathrm{~m}$ above sea level. As one of the National scenic spots in China, Mount Emei is a set of natural scenery and Buddhist culture. On 6 December 1996, Mount Emei was selected in the world heritage list. The development of Buddhism in recent 2000 years has left Mount Emei a rich Buddhist cultural heritage and made Mount Emei a profound Buddhist holy land in China and even in the world [40].

To develop and manage the scenic spots in Mount Emei, the Chinese government has set up Mount Emei tourism corporation (state capital is the controlling shareholder). According to the corporation's annual report from 2006 to 2015, tourism in Mount Emei has developed rapidly in the past ten years (Figure 2). The tourists in Mount Emei are composed of devout Buddhists and secular tourists, but the tourist behaviors and experiences for these two types of tourists are different. Buddhist tourists tend to visit and meditate at the temples, whereas non-Buddhist tourists are interested in "history, monuments, and the overall ambiance of the location" [36].

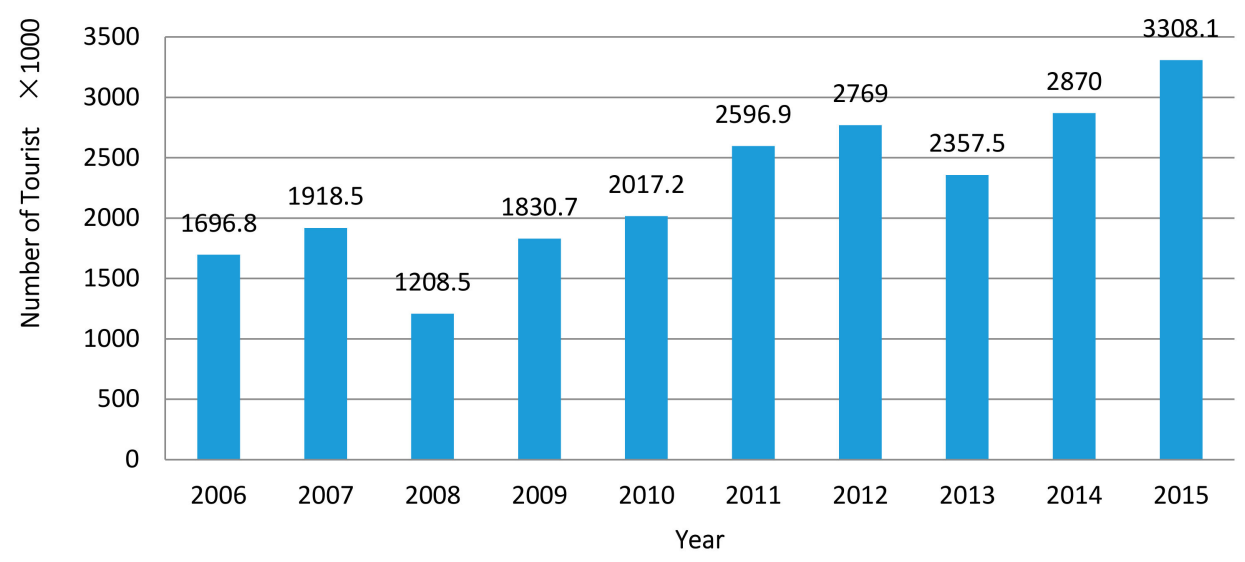

Figure 2. Tourist arrivals to Mountain Emei. Data Source: Annual Reports of Emei Shan Tourism Company Limited (2006-2015).

\subsection{Data Collection and Measures}

The sample of this study is from an onsite post-experience survey in the Mount Emei scenic spot. The onsite survey was conducted from 1 to 10 August 2015 at the tourist center of Mount Emei. The questionnaire was designed in bilingual languages (English and Chinese) and randomly sent to tourists who have completed the tour. A total of 350 questionnaires were collected and 296 questionnaires were completely answered. The effective rate of the questionnaire was $84.57 \%$. Most of the respondents were Chinese (97.57\%). Among the respondents, males accounted for $48.6 \%$ and females accounted for $51.4 \% ; 19.9 \%$ of the respondents were 20 years old or below, $38.9 \%$ were between the age of $21-30$ years old, $16.2 \%$ were between the age of $31-40$ years old, $18.6 \%$ were between the age of $41-50$ years old, and $6.4 \%$ were 51 years old or above; $22.3 \%$ of respondents obtained a high school education or less, $72 \%$ obtained a college and undergraduate education, and $5.7 \%$ obtained a graduate education; and 66.6\% of visitors were first-time traveling in Mount Emei and 33.4\% were revisiting tourists.

The measurable items for key constructs of the current research were adopted from previous studies. A seven-point Likert scale ( $1=$ strongly disagree, $7=$ strongly agree $)$ was used. The measurable items for the perceived natural environment and religious ambience were adopted primarily from Tian, Lu and Samart [21]. The measurable items for tourists' satisfaction were adopted from Yoon and Uysal [41]. The scale of awe experience was borrowed from Coghlan, Buckley and Weaver [2] 
conceptual model of awe in tourism. The awe experience was also studied in other psychological experiments. Therefore, the measurement has content validity. The semantic differential scale was adopted.

Besides the nationality, gender, age, and education background, the demographic section also includes the measurements of tourists' religious beliefs. China is not a "godless nation". There is a long and extensive influence of Buddhism on Chinese society. In 2010, the Center on Religion and Chinese Society of Purdue University found that: $85 \%$ of Chinese people have certain religious beliefs or certain religious activities, while only $15 \%$ of the Chinese are true atheists. Buddhism is the fastest growing religion in China in the past 30 years. Eighteen percent of Chinese identify themselves as Buddhists. Within Buddhists, only 1.7\% have officially converted to Buddhism. However, even among those who call themselves non-Buddhist, 31\% participated in at least one kind of Buddhist practice [42]. There is a contradictory phenomenon between the atheistic identity and religious beliefs/practices in a considerable number of Chinese people [43]. Therefore, when measuring tourists' Buddhism belief, in addition to the officially convert Buddhists and self-identified Buddhists, we also regarded the non-Buddhist who participated in at least one Buddhist activity (e.g., burning incense and praying in temples, worshiping Buddha at home, etc.) as Buddhist believers. Among the respondents, $58.8 \%$ were non-Buddhist believers, and $41.2 \%$ were Buddhist believers $(16.2 \%$ were non-Buddhist with Buddhism practices, $22 \%$ were self-identified Buddhists without officially converting to Buddhism, and $3.1 \%$ were officially convert Buddhists).

\section{Data Analyses}

\subsection{Measurement Model}

Mplus (V7) was adopted to estimate the overall fit of the measurement model and structure model through the Maximum Likelihood Method. The factor loadings, composite reliability, and average variance extracted (AVE) of the measurement model appear in Table 1. As shown in Table 1, the values of factor loadings and the composite reliability were higher than the acceptable value of 0.50 and 0.70 , respectively, showing the measurement model had acceptable convergent validity. The correlation matrix (with square roots of AVE) appears in Table 2. The square roots of AVE were higher than correlations among the corresponding latent variables [44] providing evidence of discriminant validity.

Table 1. Overall confirmatory factor analysis (CFA) for measurement model.

\begin{tabular}{|c|c|c|c|c|}
\hline \multicolumn{2}{|r|}{ Constructs and Scale Items } & $\begin{array}{l}\text { Factor } \\
\text { Loadings }\end{array}$ & $\begin{array}{l}\text { Composite } \\
\text { Reliability }\end{array}$ & $\begin{array}{l}\text { Average Variance } \\
\text { Extracted (AVE) }\end{array}$ \\
\hline \multicolumn{2}{|c|}{ Perceived Vastness of Natural Environment } & & 0.936 & 0.784 \\
\hline NE1 & $\begin{array}{l}\text { Mount Emei impresses me with its majestic } \\
\text { and precipitous appeal. }\end{array}$ & 0.908 & & \\
\hline NE2 & I feel Mount Emei is magnificent. & 0.932 & & \\
\hline NE3 & $\begin{array}{l}\text { Mount Emei shows me how strong the nature } \\
\text { is. }\end{array}$ & 0.847 & & \\
\hline NE4 & $\begin{array}{l}\text { Mount Emei gives me a fantastic display of the } \\
\text { magically beautiful scenery. }\end{array}$ & 0.852 & & \\
\hline \multicolumn{2}{|c|}{ Perceived sanctity of Religious Ambience } & & 0.917 & 0.688 \\
\hline RA1 & $\begin{array}{l}\text { The Buddhist ceremony makes me feel } \\
\text { solemnity and seriousness. }\end{array}$ & 0.854 & & \\
\hline RA2 & $\begin{array}{l}\text { In Mount Emei, I feel the powers of the } \\
\text { Buddha are unlimited. }\end{array}$ & 0.808 & & \\
\hline RA3 & $\begin{array}{l}\text { I think the Buddhist culture of Mount Emei is } \\
\text { gorgeous. }\end{array}$ & 0.881 & & \\
\hline RA4 & $\begin{array}{l}\text { I think the Buddhist arts of Mount Emei are } \\
\text { beautiful and magical. }\end{array}$ & 0.821 & & \\
\hline RA5 & $\begin{array}{l}\text { The temples in Mount Emei let me feel the long } \\
\text { history of Buddhism. }\end{array}$ & 0.779 & & \\
\hline
\end{tabular}


Table 1. Cont.

\begin{tabular}{|c|c|c|c|c|}
\hline & Constructs and Scale Items & $\begin{array}{c}\text { Factor } \\
\text { Loadings }\end{array}$ & $\begin{array}{l}\text { Composite } \\
\text { Reliability }\end{array}$ & $\begin{array}{l}\text { Average Variance } \\
\text { Extracted (AVE) }\end{array}$ \\
\hline \multicolumn{2}{|l|}{ Awe } & & \multirow[t]{5}{*}{0.871} & \multirow[t]{5}{*}{0.628} \\
\hline AW1 & boring-exciting & 0.819 & & \\
\hline AW2 & usual-unusual & 0.807 & & \\
\hline AW3 & arrogant-humbling & 0.765 & & \\
\hline AW4 & expected-unexpected & 0.778 & & \\
\hline \multicolumn{2}{|c|}{ Tourists satisfaction } & & \multirow[t]{4}{*}{0.911} & \multirow[t]{4}{*}{0.773} \\
\hline TS1 & $\begin{array}{l}\text { In general, this site was much better than I } \\
\text { expected. }\end{array}$ & 0.875 & & \\
\hline TS2 & This visit was well worth my time and effort. & 0.879 & & \\
\hline TS3 & $\begin{array}{l}\text { Overall, I was very satisfied with my holiday in } \\
\text { Mount Emei. }\end{array}$ & 0.884 & & \\
\hline
\end{tabular}

Table 2. Correlation and square root of AVE, internal consistency.

\begin{tabular}{ccccc}
\hline & $\begin{array}{c}\text { Natural } \\
\text { Environment }\end{array}$ & $\begin{array}{c}\text { Religious } \\
\text { Ambience }\end{array}$ & Awe & $\begin{array}{c}\text { Tourists' } \\
\text { Satisfaction }\end{array}$ \\
\hline Natural environment & $0.885^{\text {a }}$ & & & \\
Religious ambience & $0.435^{* *}$ & 0.829 & & \\
Awe & $0.595^{* *}$ & $0.421^{* *}$ & 0.792 & \\
Tourists' satisfaction & $0.538^{* *}$ & $0.382^{* *}$ & $0.712^{* *}$ & 0.856 \\
\hline
\end{tabular}

Note: ${ }^{* *} p<0.01$ level (2-tailed). Off-diagonal entries are two-tail correlations of latent variables. ${ }^{\text {a }}$ Figures on the diagonal are the square root of averaged variance extracted.

\subsection{Structural Equation Model}

The hypothesized structural causal model was tested by structural equation modeling (SEM). The estimates for the direct effects were provided for structural equation model to test hypotheses concerning the relationship between perceived environment (natural environment and religious ambience) and awe experience (H1), the association between awe experience and tourist's satisfaction (H2) and the mediated relationships through awe experience between perceived environment and tourists' satisfaction (H3). The model showed acceptable fit to the data (Model fit: $\chi^{2}=174.31$; $\mathrm{df}=95 ; p<0.01 ; \mathrm{CMin} / \mathrm{df}=1.83 ; \mathrm{CFI}=0.980 ; \mathrm{TLI}=0.974 ;$ SRMR $=0.037 ;$ RMSEA $=0.053$ ). As presented in Figure 3, the results offered support for the relationship between the perceived vastness of natural environment and awe (H1a) at a significant level of $0.001\left(\gamma_{11}=0.508, t=9.216\right.$; $p<0.001$ ). $\mathrm{H} 1 \mathrm{~b}$ (the perceived sanctity of religious ambience is positively related to awe) was also supported $\left(\gamma_{12}=0.2, t=3.25 ; p<0.001\right)$. The results indicate the perceived vastness of natural environment and sacred religious surroundings induce tourists' awe emotion. $\mathrm{H} 2$ tests the effect of awe experience on tourists' satisfaction. The hypothesis is supported $\left(\beta_{21}=0.59, \mathrm{t}=9.581 ; p<0.001\right)$. The finding is consistent with Shiota, Keltner and Mossman [11]. This implies that the tourists who experienced awe are likely to enjoy their journeys. The relationships established using SEM replicate closely in Table 3 by the results of the regression analysis. This provides a triangulation of the findings. The results show the effects of control variables, including gender, age, level of education, revisit times, and type of tourists, which were seen as potential antecedents to tourist's awe experience and satisfaction. Results in Table 3 indicate that tourists' perceived vastness of natural environment $(p<0.001)$ and sanctity of religious ambience are positively related with awe experience. Overall, these findings suggest that tourists are likely to have awe emotion when they are in front of a grand natural environment and sacred religious atmosphere. 
Table 3. Mediation effects and moderation effects analyses.

\begin{tabular}{|c|c|c|c|c|c|c|}
\hline & \multicolumn{4}{|c|}{ Awe } & \multicolumn{2}{|c|}{ Satisfaction } \\
\hline & Model 1 & Model 2 & Model 3 & Model 4 & Model 5 & Model 6 \\
\hline Constant & $4.895^{* * *}$ & $1.802^{* * *}$ & $5.036^{* * *}$ & $4.995^{* * *}$ & $1.572 * *$ & 0.630 \\
\hline Gender & -0.019 & 0.029 & 0.114 & -0.093 & -0.001 & -0.015 \\
\hline Age & 0.003 & 0.037 & 0.043 & -0.001 & -0.042 & -0.060 \\
\hline Education & -0.033 & -0.029 & -0.111 & -0.042 & $0.108^{*}$ & $0.122^{* * *}$ \\
\hline Revisit & 0.118 * & 0.051 & 0.066 & 0.265 * & -0.038 & -0.063 \\
\hline TY & 0.049 & 0.044 & 0.136 & 0.015 & $0.120 *$ & 0.099 \\
\hline $\mathrm{NE}$ & & $0.461^{* * *}$ & $0.467^{* * *}$ & & $0.427^{* * *}$ & $0.203^{* * *}$ \\
\hline RA & & $0.178^{* * *}$ & & $0.383^{* * *}$ & $0.165^{* *}$ & 0.078 \\
\hline Awe & & & & & & $0.468^{* * *}$ \\
\hline $\mathrm{NE}^{*} \mathrm{TY}$ & & & $-0.277^{* * *}$ & & & \\
\hline $\mathrm{RA} * \mathrm{TY}$ & & & & $0.275^{* *}$ & & \\
\hline $\mathrm{R}^{2}$ & 0.018 & 0.323 & 0.325 & 0.173 & 0.228 & 0.448 \\
\hline
\end{tabular}

Note: TY = Tourist type; NE, Natural environment; RA, Religious ambience. ${ }^{* * *} p<0.001$ level (2-tailed); ${ }^{* *} p<0.01$ level (2-tailed); ${ }^{*} p<0.05$ (2-tailed).

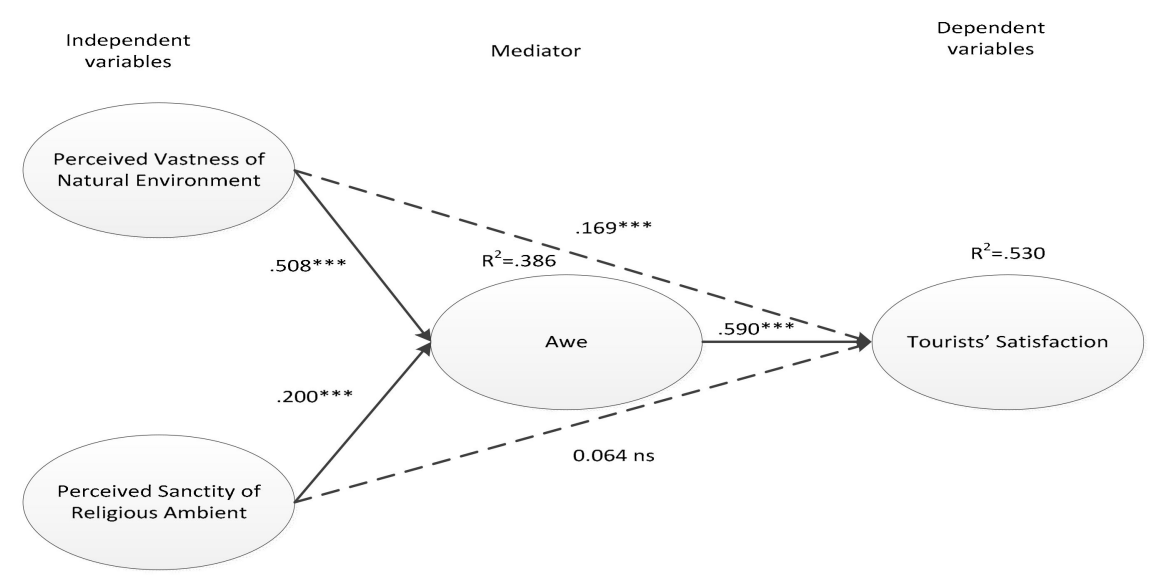

Figure 3. Structural model with standardized regression coefficients. Note: ${ }^{* * *} p<0.001 ;{ }^{* *} p<0.01$; ${ }^{*} p<0.05$. Model fit: $\chi^{2}=174.31 ; \mathrm{df}=95 ; p<0.001 ; \mathrm{CMin} / \mathrm{df}=1.83 ; \mathrm{CFI}=0.980 ; \mathrm{TLI}=0.974$; SRMR $=0.037 ;$ RMSEA $=0.053$.

\subsection{Mediation Analyses}

$\mathrm{H} 3$ assumes that there is a full mediation effect between the perceived environment (natural environment and religious ambience) and tourists' satisfaction through the awe experience. The estimates for the indirect effects were provided for the structural equation model to address these hypotheses (Table 4). According to mediation test approaches by Baron and Kenny [45], H3a receives partial support $(p<0.001)$. The relationship was not fully mediated by the awe experience since the direct relationship between the perceived vastness of natural environment and tourists' satisfaction remained significant $(p<0.001)$ (Table 4$)$. This suggests that the awe experience partially mediates the relationship between the perceived vastness of natural environment and tourists' satisfaction [46]. $\mathrm{H} 3 \mathrm{~b}$ is supported $(p<0.001)$ as the direct relationship between the perceived sanctity of religious ambience and tourists' satisfaction was not significant when awe experience was added as a predictor in the regression model (Table 4). Thus, awe experience shows a full mediating effect on the relationship between the perceived sanctity of religious ambience and tourists' satisfaction. All proposed mediation effects are supported. 
Table 4. Results with mediated effects.

\begin{tabular}{|c|c|c|c|}
\hline Hypothesis & Direct Effects & Indirect Effects & $\begin{array}{c}\text { Support/No } \\
\text { Support }\end{array}$ \\
\hline H1a: Natural Environment is positively related to awe & $0.508^{* * *}$ & & Supported \\
\hline H1b: Religious Ambience is positively related to awe & $0.200 * * *$ & & Supported \\
\hline $\mathrm{H} 2:$ Awe is positively related to tourists' satisfaction & $0.590 * * *$ & & Supported \\
\hline H3a: Natural Environment-Awe-Tourists' Satisfaction & & $0.299 * * *$ & Supported \\
\hline H3b: Religious Ambience-Awe-Tourists' Satisfaction & & $0.118^{* * *}$ & Supported \\
\hline
\end{tabular}

Note: ${ }^{* * *} p<0.001$ (2-tailed).

\subsection{Moderation Analyses}

The moderating effects (H4) of type (pilgrims/secular tourists) of tourists on the relationship between the perceived environment (natural environment and religious ambience) and visitors' awe were undertaken using ModProb (a script developed by Preacher and Hayes [47]). The interaction term model can provide an estimate and test the significance of the moderating effect. The results presented in Table 3 indicate that the type of tourists is a moderator in the relationship between the perceived vastness of natural environment and awe experience $(\beta=-0.277 ; \rho<0.001)$, and the relationship between the perceived sanctity of religious ambience and awe experience $(\beta=0.275 ; \rho<0.01)$. After testing the interaction term model, simple slope analysis is performed to compare the slopes of two types of tourists. Figures 3 and 4 show the results of simple slope analysis. In Figure 4 , the slope of the regression line of secular tourists is larger than the slope of the regression line of pilgrims. This implies that awe experience is more likely to induce by the perceived vastness of natural environment for secular tourists than for pilgrims. However, in Figure 5, the slope of the regression line of secular tourists is smaller than the slope of the regression line of pilgrims. This implies that awe experience is more likely induced by the perceived sanctity of religious ambience for pilgrims than for secular tourists. The results support H4a and H4b.

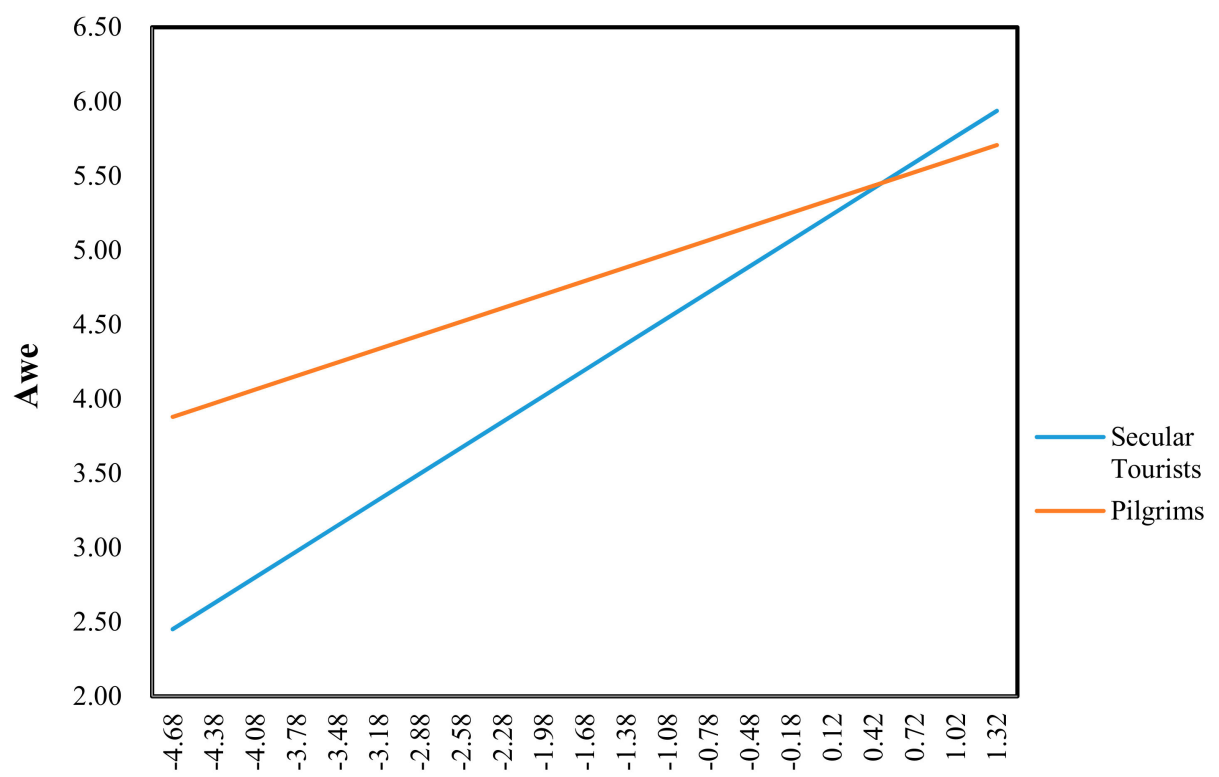

\section{Perceived vastness of natural environment}

Figure 4. Interactive effects of perceived vastness of natural environment and tourist type on awe. 


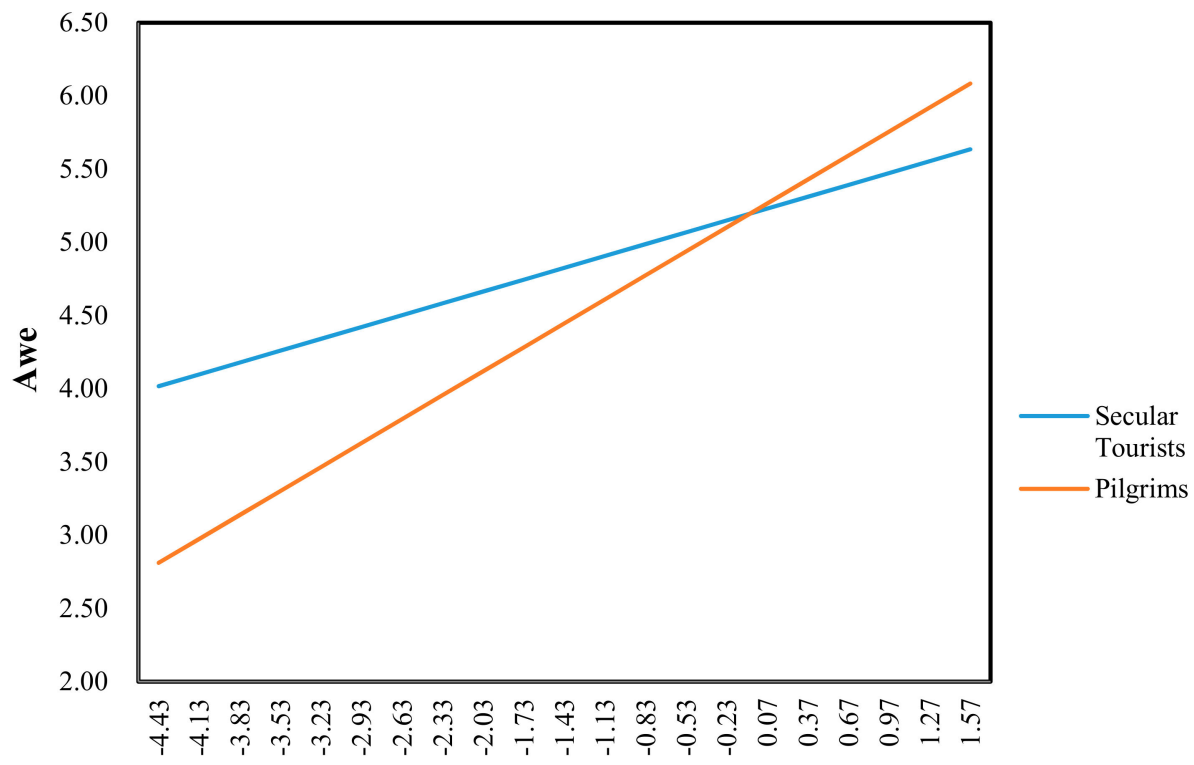

Perceived sanctivity of religious ambience

Figure 5. Interactive effects of perceived sanctity of religious ambience and tourist type on awe.

\subsection{Moderated Mediation Analyses}

The moderated mediation effects (H5) of a type of tourists was undertaken by using PROCESS (a script developed by Hayes [48]). Model 7 was used to estimate the significance of the interaction terms. The results are presented in Table 5 . To test the significance of conditional indirect effects of the perceived environment (natural environment and religious ambience) through awe experience on tourists' satisfaction, we used boot estimates from 5000 bootstrap samples. The findings suggest that conditional indirect relationship of the perceived vastness of natural environment with tourists' satisfaction through awe experience was significant, and the indirect effect for secular tourists was larger than pilgrims (tourists: boot indirect effect $=0.3188$, Boot LLCI $=0.2284$, Boot ULCI $=0.4240$; pilgrims: boot indirect $=0.1671$, Boot LLCI $=0.0761$, Boot ULCI $=0.2827$ ) (shown in Table 5). The results support H5a. The findings also indicate the significant result for conditional indirect relationship of the perceived sanctity of religious ambience with tourists' satisfaction through awe experience, and the indirect effect for secular tourists was smaller than pilgrims (secular tourists: boot indirect effect $=0.1662$, Boot LLCI $=0.0736$, Boot $\mathrm{ULCI}=0.2693$; pilgrims: boot indirect $=0.3363$, Boot LLCI $=0.1952$, Boot ULCI $=0.5039$ ) (shown in Table 5). H5b is supported.

Table 5. Conditional indirect effects of perceived environment on tourists' satisfaction for different tourist type.

\begin{tabular}{cccccc}
\hline \multirow{2}{*}{ Predictors } & \multirow{2}{*}{ Type of Tourists } & \multicolumn{3}{c}{ Tourists' Satisfaction } \\
\cline { 3 - 6 } & & Indirect Effect & Boot Se & Boot LLCI & Boot ULCI \\
\hline Perceived vastness of & Tourists & 0.3188 & 0.0501 & 0.2284 & 0.4240 \\
natural environment & Pilgrims & 0.1671 & 0.0535 & 0.0761 & 0.2827 \\
\hline Perceived sanctity of & Tourists & 0.1662 & 0.0469 & 0.0736 & 0.2693 \\
religious ambience & Pilgrims & 0.3363 & 0.0778 & 0.1952 & 0.5039 \\
\hline
\end{tabular}

\section{Conclusions}

Mountain tourism is an economic pillar in some regions in China and sacred mountains have become popular attractions owing to their magnificent mountain scenery and legendary prominence. Therefore, mountain tourism is regarded as one of the region's major economic sources in China. 
This study shows how tourists' perceptions of "awesomeness" for a sacred mountain attraction can transfer to awe experience and satisfaction. This study also finds which factors encourage awe and what the boundary conditions are. The tourists' perceived vastness of natural environment and sanctity of religious ambience elicits their awe experience (with the type of tourists as a moderator) and lead to their satisfaction. Since enhancing tourist satisfaction is an important aspect of economic sustainability for mountain tourism, which supports local economies [49], this study has achieved its aim to examine the role of awe as an important emotional experience in sustainable tourism.

For pilgrims, sacred mountains are also spiritually significant as holy sites. The awe experience in sacred mountain tourism for pilgrims and secular tourists are quite different. This paper has provided evidence that the awe experience is more elicited by the perceived vastness of natural environment for secular tourists, while it is more encouraged by the perceived sanctity of religious ambience for pilgrims. The findings of this research are consistent with Preston and Shin [39] study that religious people recalled more religious events as sources of awe, and non-religious visitors were more likely to experience awe in nature. This study also indicates that the awe experience is a critical mediator between a sense of perceptual vastness/sanctity and tourists' satisfaction. This study also confirms that these mediation relationships through awe experiences are moderated by the type of tourists.

Overall, this study makes several contributions. First, the current research is one of the first investigations on the awe experience of different types of tourists. The results show that, when visiting religious mountains, the sources of awe are a natural environment for secular tourists and religious ambience for pilgrims. Second, the findings reveal that the awe experience is a critical mediator between tourists' perception of vastness/sanctity and tourists' satisfaction since it fully mediates the relationship between the perceived sanctity of religious ambience and tourists' satisfaction and partially mediates the relationship between the perceived vastness of natural environment and tourists' satisfaction. Third, this study is one of the first in the sustainable tourism studies using the moderated mediation analysis to investigate the complex relationships between the perception of vastness and sanctity and tourists' satisfaction through awe experience with the type of tourists as a moderator. This technique advances theory development by comparing with analyzing the simple direct relationship between independent variables and dependent variables [50].

\subsection{Practical/Managerial Implications}

There are two practical applications for destination operators and managers based on the results of this research. First, the high variance explained in tourists' satisfaction suggests that the awe experience is the critical mechanism linking tourists' perceived surroundings and satisfaction. Therefore, destination marketers should apply tourism strategies to encourage tourists' sense of awe. For example, when designing a tour product, tour managers should include some awe elements such as visiting the most spectacular historic buildings, scenery, and temples in order to enhance the tourists' awe experience during travel.

Second, this research identifies the sources of tourists' awe in mountain destinations. For secular tourists, the awe experience is mainly from the perceived vastness of natural environment. For pious pilgrims, the awe experience is mainly from the perceived sanctity of religious ambience. Destination operators need to subdivide the tourist market. For secular tourists, beautiful natural landscapes should be concerned and viewpoints accessing to panoramic view should be increased in the scenic spots in order to increase the awe experience opportunity for secular tourists. For pious pilgrims, important religious ceremonies should be held in order to increase opportunities for pilgrims to participate in religious activities as much as possible and raise the pilgrims' awe experience.

\subsection{Limitations and Research Implications}

In this study, an onsite post-experience survey was used to study the tourists' awe experience. However, attention should be paid to the interpretation of the findings. First, the generalizability of the research conclusions may be limited. On the one hand, this study examined the awe experience in 
Buddhism only. Other religions have not been included in the study such as Taoism, Christianity, and Islam. Although Preston and Shin [39] research found that the Christians' awe experience is mainly derived from religious events, further explorations are needed to analyze whether the awe experience of other religious pilgrims' (e.g., Taoism, Islam, etc.) is mainly derived from the perception of religious atmosphere. On the other hand, the majority of tourists in this study are local tourists, while only $2.43 \%$ are international tourists. It is worth discussing whether there are cultural differences (e.g., tourists from different countries) on the awe experience generation and the awe experience effects. In the future, it is necessary to study the awe experience of tourists with a Western cultural background to test the research model.

Secondly, cross-sectional data were used in this study. Therefore, the causal relationship established by the research model may be weakened. However, we still insist that the causal relationship proposed in the hypotheses of this study is highly possible. The existing theoretical literature reveals that the perceived vastness of the physical environment and the sense of "small self" towards the religion are two important stimuli of the experience of awe [3]. The awe experience extends the connection between the individuals and the outside world, which leads to the satisfaction of individuals [11]. The causality of our proposed model is supported. Future research can be designed through experimental or quasi-experimental studies to address this issue.

Acknowledgments: The authors gratefully acknowledge the financial support of the research project of Humanity and Social Science Youth foundation of Ministry of Education of China (15XJC790008), the research foundation of Education Bureau of Sichuan Province (16SA0014), the research project of Philosophy and Social Science Foundation of Sichuan Province of China (SC17B077), and the support of FRG funding of Macau University of Science and Technology.

Author Contributions: Dong Lu has contributed in developing the research ideas, conducting the research, analyzing the data, and writing the manuscript. Yide Liu provided efforts on research design, data analysis, and manuscript writing. Ivan Lai wrote the manuscript and provided data analysis consultancy. Li Yang assisted with the research process. All authors read and approved the final manuscript.

Conflicts of Interest: The authors declare no conflict of interest.

\section{References}

1. Pearce, P.L. The Relationship between Positive Psychology and Tourist Behavior Studies. Tour. Anal. 2009, 14, 37-48. [CrossRef]

2. Coghlan, A.; Buckley, R.; Weaver, D. A Framework for Analysing Awe in Tourism Experiences. Ann. Tour. Res. 2012, 39, 1710-1714. [CrossRef]

3. Keltner, D.; Haidt, J. Approaching Awe, A Moral, Spiritual, and Aesthetic Emotion. Cogn. Emot. 2003, 17, 297-314. [CrossRef]

4. Turner, V.W.; Turner, E.L.B. Image and Pilgrimage in Christian Culture: Anthropological Perspectives; Basil Blackwell: Oxford, UK, 1978.

5. Powell, R.B.; Brownlee, M.T.; Kellert, S.R.; Ham, S.H. From Awe to Satisfaction: Immediate Affective Responses to the Antarctic Tour. Experience. Polar Rec. 2012, 48, 145-156. [CrossRef]

6. Hughes, G. The Cultural Construction of Sustainable Tourism. Tour. Manag. 1995, 16, 49-59. [CrossRef]

7. Bramwell, B.; Lane, B. Sustainable Tourism: An Evolving Global Approach. J. Sustain. Tour. 1993, 1, 1-5. [CrossRef]

8. Okello, M.M.; Yerian, S. Tourist Satisfaction in Relation to Attractions and Implications for Conservation in the Protected Areas of the Northern Circuit, Tanzania. J. Sustain. Tour. 2009, 17, 605-625. [CrossRef]

9. Romeril, M. Tourism and the Environment-Accord or Discord. Tour. Manag. 1989, 10, 204-208. [CrossRef]

10. UNWTO. Sustainable Development of Tour. Available online: http://sdt.unwto.org/content/about-us-5 (accessed on 26 October 2017).

11. Shiota, M.N.; Keltner, D.; Mossman, A. The Nature of Awe: Elicitors, Appraisals, and Effects on Self-Concept. Cogn. Emot. 2007, 21, 944-963. [CrossRef]

12. Schneider, K.J. Awakening to an Awe-Based Psychology. Humanist. Psychol. 2011, 39, 247-252. [CrossRef]

13. Konecni, V.J. The Aesthetic Trinity: Awe, Being Moved, Thrills. Bull. Psychol. Arts 2005, 5, 27-44.

14. Arnold, M.B. Emotion and Personality; Columbia University Press: New York, NY, USA, 1960. 
15. Lazarus, R.S. Psychological Stress and the Coping Process; McGraw-Hill: New York, NY, USA, 1966.

16. Pulido-Fernández, U.I.; López-Sánchez, Y. Are Tourists Really Willing to Pay More for Sustainable Destinations? Sustainability 2016, 8, 1240. [CrossRef]

17. Crouch, G.I. Environment-Friendly Tourists: What Do We Really Know About Them? J. Sustain. Tour. 2008, 16, 197-210.

18. Gilg, A.; Barr, S.; Ford, N. Green Consumption or Sustainable Lifestyles? Identifying the Sustainable Consumer. Futures 2005, 37, 481-504. [CrossRef]

19. Freytag, A.; Vietze, C. Can Nature Promote Development? The Role of Sustainable Tourism for Economic Growth. J. Environ. Econ. Policy 2013, 2, 16-44.

20. Lu, D.; Chang, P.; Wang, C.; Tian, Y.; Samart, P. Would Tourists Experienced Awe Be More Ethical? An Explanatory Research Based on Experimental Method. Tour. Trib. 2016, 31, 51-61.

21. Tian, Y.; Lu, D.; Samart, P. Tourist's Awe and Loyalty: An Explanation Based on the Appraisal Theory. Tour. Trib. 2015, 30, 80-88.

22. Picard, D. Tourism, Awe and Inner Journeys. In Emotion in Motion: Tourism, Affect and Transformation; Picard, D., Robinson, M., Eds.; Ashgate Publishing Company: Surrey, UK, 2012.

23. Cohen, A.B.; Gruber, J.; Keltner, D. Comparing Spiritual Transformations and Experiences of Profound Beauty. Psychol. Relig. Spiritual. 2010, 2, 127-135. [CrossRef]

24. Meier, B.P.; Hauser, D.; Robinson, M.D.; Friesen, C.K.; Schjeldahl, K. What's "up" with God? Vertical Space as a Representation of the Divine. J. Pers. Soc. Psychol. 2007, 93, 699-710. [CrossRef] [PubMed]

25. Piff, P.K.; Dietze, P.; Feinberg, M.; Stancato, D.M.; Keltner, D. Awe, the Small Self, and Prosocial Behavior. J. Pers. Soc. Psychol. 2015, 108, 883-899. [CrossRef] [PubMed]

26. Spears, R.; Leach, C.; Zomeren, M.V.; Ispas, A.; Sweetman, J.; Tausch, N. Intergroup Emotions: More Than the Sum of the Parts. In Emotion Regulation and Well-Being; Nyklicek, I., Vingerhoets, A., Zeelenberg, M., Eds.; Springer: New York, NY, USA, 2011; pp. 121-145.

27. Van Cappellen, P.; Saroglou, V. Awe Activates Religious and Spiritual Feelings and Behavioral Intentions. Psychol. Relig. Spiritual. 2012, 4, 223-236. [CrossRef]

28. Rudd, M.; Vohs, K.D.; Aaker, J. Awe Expands People's Perception of Time, Alters Decision Making, and Enhances Well-Being. Psychol. Sci. 2012, 23, 1130-1136. [CrossRef] [PubMed]

29. Bigne, J.E.; Andreu, L.; Gnoth, J. The Theme Park Experience: An Anal. of Pleasure, Arousal and Satisfaction. Tour. Manag. 2005, 26, 833-844. [CrossRef]

30. Relph, E. Place and Placelessness; Pion: London, UK, 2008.

31. Poria, Y.; Butler, R.; Airey, D. The Core of Heritage Tourism. Ann. Tour. Res. 2003, 1, 238-254. [CrossRef]

32. Levin, S. Understanding Religious Behavior. J. Relig. Health 1979, 1, 8-20. [CrossRef] [PubMed]

33. Mattila, A.S.; Apostolopoulos, Y.; Sonmez, S.; Yu, L.; Sasidharan, V. The Impact of Gender and Religion on College Students' Spring Break Behavior. J. Travel Res. 2001, 40, 193-200. [CrossRef]

34. Rinschede, G. Forms of Religious Tourism. Ann. Tour. Res. 1992, 19, 51-67. [CrossRef]

35. Collins-Kreiner, N. Researching Pilgrimage: Continuity and Transformations. Ann. Tour. Res. 2010, 37, 440-456. [CrossRef]

36. Nyaupane, G.P.; Timothy, D.J.; Poudel, S. Understanding Tourists in Religious Destinations: A Social Distance Perspective. Tour. Manag. 2015, 48, 343-353. [CrossRef]

37. Cohen, E. Pilgrimage and Tourism: Convergence and Divergence. In Sacred Journey: The Anthropology of Pilgrimage; Morinis, A., Ed.; Greenwood Press: Westport, New Zealand, 1992; pp. 47-61.

38. Turner, V.W. The Center out There: Pilgrim's Goal. Hist. Relig. 1973, 12, 191-230. [CrossRef]

39. Preston, J.L.; Shin, F. Spiritual Experiences Evoke Awe through the Small Self in Both Religious and Non-Religious Individuals. J. Exp. Soc. Psychol. 2017, 70, 212-221. [CrossRef]

40. MEAC. Mount Emei Scenic Overivew. Available online: http://www.ems517.com/channel/jingqugaikuang. html (accessed on 18 September 2017).

41. Yoon, Y.; Uysal, M. An Examination of the Effects of Motivation and Satisfaction on Destination Loyalty: A Structural Model. Tour. Manag. 2005, 26, 45-46. [CrossRef]

42. Li, X.; Wang, Y. Center on Religion and Chinese Society of Purdue University: Up to 30 Million. Chinese National Daily. 24 August 2010. Available online: http:/ / minzu.people.com.cn/GB/166717/12529774. html (accessed on 28 October 2017). 
43. Yang, C.K. Religion in Chinese Society: A Study of Contemporary Social Functions of Religion and Some of Their Historical Factors; University of California Press: Berkeley, UK, 1961.

44. Fornell, C.; Larcker, D.F. Evaluating Structural Equation Models with Unobservable Variables and Measurement Error. J. Mark. Res. 1981, 18, 39-50. [CrossRef]

45. Baron, R.M.; Kenny, D.A. The Moderator-Mediator Variable Distinction in Social Psychological Research: Conceptual, Strategic, and Statistical Considerations. J. Pers. Soc. Psychol. 1986, 51, 1173-1182. [CrossRef] [PubMed]

46. Zhao, X.; John, G.; Lynch, J.; Chen, Q. Reconsidering Baron and Kenny: Myths and Truths About Mediation Analysis. J. Consum. Res. 2010, 37, 197-206. [CrossRef]

47. Preacher, K.J.; Hayes, A.F. Asymptotic and Resampling Strategies for Assessing and Comparing Indirect Effects in Multiple Mediator Models. Behav. Res. Methods 2008, 40, 879-891. [CrossRef] [PubMed]

48. Hayes, A.F. Process: A Versatile Computational Tool for Observed Variable Mediation, Moderation, and Conditional Process Modelling (White Paper). Analysis. 2012. Available online: http:/ / www.afhayes. $\mathrm{com} /$ public/process2012.pdf (accessed on 28 October 2017).

49. Eber, S. Beyond the Green Horizon: A Discussion Paper on Principles for Sustainable Tourism; WWF and Tourism Concern: London, UK, 1992.

50. Ramkissoon, H.; Mavondo, F.T. The Satisfaction-Place Attachment Relationship: Potential Mediators and Moderators. J. Bus. Res. 2015, 68, 2593-2602. [CrossRef]

(C) 2017 by the authors. Licensee MDPI, Basel, Switzerland. This article is an open access article distributed under the terms and conditions of the Creative Commons Attribution (CC BY) license (http:/ / creativecommons.org/licenses/by/4.0/). 